\title{
THE ROLE OF STUDENT ETHICS IN THE LEARNING DEVELOPMENT PROCESS AT POLIMDO ACCOUNTING DEPARTMENT
}

\author{
Kiet Tumiwa, Jolly Turangan, Ruhiyat, Roslina H.S.D. Limpeleh \\ Department Of Accounting, Polytechnic of Manado Country \\ DOI: $10.31364 / S C I R J / v 8 . i 9.2020 . P 0920804$ \\ http://dx.doi.org/10.31364/SCIRJ/v8.i9.2020.P0920804
}

\begin{abstract}
The purpose of this research to determine students' understanding of ethics in the learning development process in the Polimdo accounting department. The research method used is descriptive qualitative method, which describes and describes, the impact of the ethical role of students in the learning development process in the Polimdo accounting department. Data collection techniques, namely by direct observation, interviews using six informants, namely five students and one lecturer, and supported by literature study. The results showed that the role of student ethics, in the learning development process in the Polimdo accounting department, has been implemented properly, and is in accordance with what is taught by the lecturer, namely; present on time, politeness, responsibility, cooperation, socialization, and mutual respect
\end{abstract}

\section{Keywords: Ethics, Students, Development, Learning}

\section{INTRODUCTION}

Ethics for students is a habit of how to behave, both in daily life in class, at home and in the community. The existence of ethics that is upheld and respected by students and lecturers, of course, has an important reason that needs attention. There are several ethical benefits for students, namely: giving a sense of responsibility, can be used as a guide, increase the credibility of the company or organization, create order, and order in an organization or company, can be used as social control, can improve the welfare of members, can prevent interference from outsiders, can protect the rights of members and workers, and can be used as a reference in resolving various weaknesses. Weaknesses in individual and corporate greed, providing services that reduce independence, being too lenient with clients and participating in avoiding existing accounting rules. To avoid these things, accounting educating accountants on two things, namely appreciation of the accounting profession, and appreciation regarding ethical dilemmas. This can be expressed in the form of subjects, teaching methods to curriculum preparation based on ethical values.

Ethics itself has become an interesting thing to talk about. Triggered by the occurrence of a mega scandal, which befell several large companies in the world, involving the accountant profession. Therefore, accounting education needs to contain ethical teachings, which are very relevant to be conveyed to students. Regardless of how it looks, ethics education has been recognized has a very important role in the development of the accounting profession, especially in Indonesia, is to produce accountants with high ethics. With high ethical accountants, it is hoped that the objectives of financial reports can be achieved, namely to provide information needed by users, so that in preparing financial reports, it will be separated from the behavior of managers who tend to apply accounting policies that tend to be liberal, depending on the desired reporting value. . Based on the above background, the researchers formulated the following problem formulations: The Role of Student Ethics in the Learning Development Process in the Polimdo Accounting Department.

\section{RESEARCH METHODS}

This research method is carried out using a descriptive qualitative approach because the problems to be discussed do not agree with numbers but describe the role of student ethics in the learning development process in the Polimdo accounting department. Data sources, namely: Primary data, namely data obtained directly from interviews with informants. The informants in this study were six people, namely five students, and one lecturer. Secondary data, namely data that researchers get from libraries and references on the internet. Data collection techniques, through observation and interviews. Data analysis, in general, the data analysis used is descriptive qualitative analysis, namely analysis that is not based on statistical calculations in the form of quantitative but in the form of statements and descriptions that will be systematically compiled.

\section{DISCUSSION}

\subsection{The Role of Ethics in Learning Development at Polimdo Accounting Department}

"Lecturer D.R. stated that the development of learning at Polimdo, majoring in accounting, is a process of interaction between lecturers and students, and is supported by the elements in it. Subject matter, 
infrastructure, learning conditions, learning media, learning environment, learning methods, evaluation, and good ethics. All of these are elements of learning development, which influence the success of the teaching and learning process, as well as increase student learning achievement. The teaching and learning process is influenced by factors from within the institution as well as from students, including a fun learning model".

In this research, it is hoped that courses that discuss ethics can provide good benefits for students, especially in the following process:

\section{a. Students Are Proud to Enter Classes Never Too Late}

Students who attend on time are certainly proud and highly appreciated by the lecturers, on the other hand, lecturers are present on time, a disciplined personal trust will arise, and are also appreciated by students.

A.M student: "I always come on time because I am embarrassed by the lecturer if I am late. I am proud to be on time. This is training my character, to become a better person. My suggestion is that the punishment should be increased for students who violate the rules".

N.B Student: "Often late, I believe it will affect my grades, and maybe my graduation could be delayed. Therefore, I always try not to be late for class".

M.S Student: "I was scolded by the lecturer because I was often late so my grades were not optimal but since then I have never been late again". It turned out that when I started not too late, my grades got better, and that was a pride for me.

D.R Lecturer: "I am not happy to see students often late, of course there is a separate assessment between students who are diligent and students often ask for permission or skip class/ lazy. I always motivate students in the teaching and learning process to be concentrated, interactive, enthusiastic, and enter lectures on time ".

S Student : "I always try to get to class on time so I don't miss the subjects. I am very proud when I graduate on time".

Present on time in every lecture, of course for these students to feel proud, and will have a good impact on these students, namely students can attend lectures well, have good grades, and graduate on time. Graduating on time, of course, will save tuition fees, be able to reach your goals faster, be proud of your graduation with classmates, parents are proud to graduate on time, and are not ashamed to be said to be immortal students. Being present on time will provide added value for students in the eyes of the lecturers because they are considered to have good ethics. Good ethics, can be seen from the card that makes students proud. Good grades are a reflection of these students, who have good ethical attitudes, towards the existing lecture process. By being present on time, the assignments given by the lecturer can be completed properly.

T.H student: "I am always present on time in class, afraid that I will miss the lessons delivered by the lecturers. Likewise, when I get an assignment I always try to make it well ".

College assignments in the accounting department itself are one way for lecturers to measure the extent to which students' abilities can understand the lessons given during the lecture process. In the lecture process, it shows a real picture, the good and bad ethical behavior of students.

\section{b. Behavior of Educated People}

Students are educated people, whose daily behavior will be an example for their fellow students. If students behave well, then unconsciously their behavior has had a positive influence on friends around them, or vice versa if students behave poorly, then without realizing it has also had a negative influence on students around them. Polite manners, the rules of life that arise from the association of a group of students, namely: Obeying institutional regulations, respecting lecturers, accepting everything with the right hand, not saying dirty words (harsh), not spitting in any place, not interrupting conversations and dressing modestly.

D.R Lecturer: "I like seeing polite students, even though the students are mediocre, not very smart. I judge students as a whole, not just by their intelligence. I often remind students to be polite, or not to come in and out during the teaching and learning process in class".

A.M student: "Meeting my lecturer always gives greetings. Likewise in class, I always behave politely to the lecturer when he teaches ".

N.B Student : "On campus I always dress neatly and cleanly, and when communicating with lecturers in class and outside the classroom, I always act politely and really appreciate it". 
Manners are the most important thing. All ethical and moral values can be applied, when students are polite. How to dress and speak, when on campus or in society, must be in accordance with the attitude of educated people who want to understand the meaning of ethics. Judging from the way of speaking with the lecturer must use polite and polite words.

T.H student: "When talking to the lecturer, I was very careful, afraid that the lecturer would be offended. So, I always use polite words".

M.S student: "I personally meet lecturers or older people, I always greet you".

S Student : "It is mandatory for me to greet older people, and I also pay attention to how to dress".

When you run into lecturers, campus staff, cleaning services, or older people, don't be indifferent, a student is obliged to greet politely. This is a commendable attitude that must be done by Polimdo students, especially accounting majors. This commendable attitude must be a good culture, so that one day it can be an example for colleagues at work, or the community around them. Likewise, when communicating, the lecturer does not interrupt the conversation with the lecturer or with the students. Able to dress neatly and politely: a). Wear neat clothes and shoes. b). do not wear shirts / shirts without sleeves or collars. c). no tight clothes and miniskirts for female students. d). do not dress using transparent / transparent materials. This is a commendable attitude, one that needs to be emulated as a student. This commendable attitude, of course, when in college students are able to correctly understand the meaning of ethics at the Polimdo campus.

\section{c. Awareness of Responsibility}

Responsibility towards oneself requires the awareness of each student to fulfill his own obligations in developing his personality as an ethical human being. This responsibility is evidenced by the student's compliance with the rules applied in Polimdo, especially the accounting department.

D.R Lecturer: "As a lecturer I teach, awaken and motivate students to have responsibility for themselves, their families, institutions and society".

Responsibility towards oneself is very important, it is taught to students because with this responsibility students are able to learn even harder, so that they can finish their studies on time with satisfactory grades. With students finishing on time, with satisfying grades, of course the family, especially parents feel proud of their child's success. Responsibility to the institution as a student, is required to pay single tuition fees on time, while responsibility to the community makes the campus atmosphere conducive, and is able to keep campus assets / facilities clean and functioning properly.

A.M student: "Responsibility, train me to live independently, and always try to have good ethics to everyone, and keep the campus environment safe and clean. So is the responsibility as a student. I am never late in paying the single tuition fee because I am afraid that I will not be able to go to college ".

T.H student: "As a student, I am obliged to pay a single tuition fee because I have received the right as a student, which is a course at Polimdo accounting major. Therefore, the three parents gave money to pay a single tuition fee, I paid immediately. I never late to pay single tuition ".

Paying single tuition on time, of course, is very good for these students because they can attend classes regularly. Single tuition fees are late, very detrimental to these students, and interfere with lecture activities because students will be given leave sanctions.

M.S Student: I am afraid of getting sanctioned on leave because it is very scary for me. Therefore, I always pay my single tuition on time.

N.B Student : "When I got a shipment from my parents to pay the single tuition fee, I immediately paid it because I felt sorry for Mama and Papa".

Therefore, students must be able to protect their parents' feelings. If the money is sent for a single tuition fee, use it properly to pay the single tuition fee, don't use the money for unnecessary things. Responsibilities as a student, have a target to pass on time.

S Student : "I am ashamed to be late in paying the single tuition fee because I know that the single tuition fee will later become a lecturer salary. I always pay my single tuition on time. I am afraid of being penalized for leave, and want to graduate on time".

Graduating on time, of course, it takes a struggle to have an attitude of never giving up. The assignments given by the lecturer are completed on time. Entering college is never late and actively asks if something material is deemed not understood. Attitudes in class and outside the classroom must be polite. 


\section{d. Social interactions}

Social interaction is a form of cooperation with an associative nature that occurs when groups of students who have the same views achieve common goals.

D.R Lecturer: When making group assignments, I am very happy that students are active. I said who is active, of course, the value is different from those who are not active. The goal is to motivate students to have togetherness in making assignments ".

A.M student: "As a student, I can't live alone. In my experience working with several friends the results will be better".

N.B Student : Group work trains me patience.

M.S Student: "Group cooperation, the benefit of being able to respect friends' opinions, as well as friends can respect my opinion".

TH \& S students: "Group cooperation fosters a sense of togetherness".

As social creatures, of course, students cannot rely on themselves to get maximum results. Collaboration will be able to provide many benefits, when a group assignment is given by the lecturer to do it together. Benefits of student cooperation when completing group work: a). Group assignments will be easier to complete. b). Group assignments can train each individual to issue opinions, suggestions, criticism and respect the opinions of others, when sitting together completing group assignments. c). Group assignments will be easier to achieve the desired goals. d). Group assignments are able to foster a group learning spirit, and foster a sense of brotherhood. Collaboration can be a learning material for students while sitting in college. Building cooperation will be easier than working alone. Therefore, as a student it is necessary to foster cooperation, so that group assignments, or assignments that involve more than one student, can be completed properly.

\section{e. Positive Associations}

Positive association, or socializing, is a learning process carried out by students to act, or behave based on standards that will be recognized by Polimdo, especially accounting majors. Socializing students to learn, and adjusting to values, norms, behavior, customs, and all other requirements needed to play a role and function in the lecture process.

A.M student: "As a student you must be good at socializing so you can find out about developments on campus".

N.B Student : "Socialization is necessary, sometimes I get sick, so my friends call and tell me the assignment given by the lecturer".

M.S Students: Positive associations are needed by a student, without association it feels empty "

T.H students: Socialization can make many friends.

S Student : "By socializing, we as students can exchange information. I think socializing can also increase enthusiasm for learning. "

Socializing with friends, the socialization process is an active process, that is, a student belongs to a group. If students can adjust to the changes that occur in the social environment, these students will continue to grow and develop together with other students. Why do students need to socialize on campus because students are social creatures and cannot live alone. When students can understand the differences in both characteristics, culture and customs, and are able to learn values, norms and roles, then these students will live well on campus, or where the student lives. As it is known that the world of campus, not only teaches us in teaching value targets, but also implies teaching students how to interact with friends on campus. Therefore, in campus life, the opportunities for students to develop their personal life are so great. Student life is a life full of struggles, away from parents and have to work work for a bright future. This hard student life is a lesson for the formation of human nature.

\section{f. Creating Harmony}

D.R Lecturer: "At the morning prayer or opening for teaching, I often give the opportunity to pray to students, even though I don't share my religion. Likewise in terms of grading, I am never choosy. I give grades according to the students' abilities.

A.M student: Mutual respect is a fundamental thing to create a harmonious life. I hang out with students regardless of their religion

N.B Student: "I really appreciate friends, both in terms of religion and different cultures". 
Multiculturalism opens up space for students to respect each other's differences, even though there are inconveniences. Mutual respect on campus must be upheld because students are required to be tolerant and respectful between groups, or between individuals, be it in the campus environment or in other environments. This is because each campus is followed by students from various regions, who have differences in language, culture and religion. The formation of a student's character, seen from how these students respect each other among fellow students, at the same level, as well as seniors and juniors, as well as lecturers and employees. Mutual respect is very visible when holding group discussions, or group assignments. How ethics of mutual respect will emerge among fellow students.

S \& T.H Student: "I really appreciate the lecturer when the lecturer teaches, or during class discussions. The attitude of mutual respect will certainly make the classroom atmosphere more comfortable for studying ".

M.S Students: "I often respect each other, for example, accept friends' opinions during class discussions, or in order to complete group assignments".

When completing group assignments or class discussions, interactions / opinions of fellow friends must be respected, even if they are not correct. Then, discussed patiently to find the correct answer solution. Most importantly, that opinion must be accepted first, not rejected before discussion. Attitudes like this need to be exemplified, in order to create good ethics in terms of mutual respect for fellow friends on the Polimdo campus, especially in the accounting department.

\subsection{Research result}

Ethics for students is often understood as behavior which contains rules about how students should be disciplined, namely which ones must be obeyed, and prohibitions that must be avoided on campus. The words of the lecturers and students above, which are of concern in the development of learning at Polimdo, majoring in accounting, are living ethically well as students, so that they can graduate according to their dreams. Given that student ethics is very important in motivating and supporting the learning development process at Polimdo. The results of a number of data revealed from interviews with students are: a). Be on Time. b). Politeness. c). Responsible. d). Cooperation. e). Get social. f). Mutual respect is a factor that plays a role in student ethics in the learning development process in the Polimdo accounting department.

\section{a. Be on Time}

Being present on time in every lecture, of course for students will have a good impact on these students, namely students can attend lectures from beginning to end well, and can graduate on time. Graduating on time will certainly save the cost of single tuition fees, be able to reach goals faster, be proud of graduating with classmates, parents are very proud because their children graduate on time, they are not ashamed to say that students are eternal and will be very appreciated so that a personal trust arises disciplined student. In addition to being appreciated, when it comes on time, it also gets used to being able to live a disciplined life in life. Being present on time will provide added value to students in the eyes of the lecturers because they are considered to have good ethics.

Good ethics can be seen from the proud student study results card. Good grades are a reflection of these students having good ethical attitudes towards the existing lecture process. By being present on time, the assignments given by the lecturer can be completed properly. College assignments in the accounting department itself are one way for lecturers to measure the extent to which students are able to understand the lessons given during the lecture process. In the lecture process, it shows a real picture of good and bad student behavior. Being present on time as indicated by these students is part of the role of student ethics in the learning development process in the Polimdo accounting department.

\section{b. Politeness}

Polite manners are the rules of life that arise from the association of a group of students, namely: Obeying institutional regulations, respecting lecturers, respecting the lessons described by the lecturers, not saying dirty words (harsh), not spitting in any place, not interrupting conversations and dressing politely. Students are educated people, where their daily behavior will be an example for their fellow students. If students behave well, then without realizing their behavior has been assessed by the lecturer, and can have a positive influence on friends around them, or vice versa if students behave poorly, then without realizing it has also had a negative influence on other students. Manners are the most important thing. If students are able to behave in a polite manner, then all moral values can be applied, and can be enjoyed by other students around them. How to dress and speak when on campus or in society, must be in accordance with the attitude of educated people who want to understand the meaning of ethics.

The meaning of ethics can be seen from the way you talk to the lecturer by using polite and polite words. When you run into lecturers, campus staff, cleaning services, or older people, don't be indifferent, a student is obliged to greet politely. This commendable attitude must become a good culture so that one day it can be an example for fellow workers, or the surrounding community. Likewise, when communicating, the lecturer does not interrupt the conversation with the lecturer or with the students. Able to dress neatly and politely: a). Wear neat clothes and shoes. b). do not wear shirts / shirts without sleeves or collars. c). no tight clothes and miniskirts for female students. d). do not dress using transparent / transparent materials. This is a commendable attitude, one that needs to be emulated as a student. This commendable attitude is of course when students are able to correctly understand the meaning of ethics at the Polimdo campus. The courtesy shown by these students is part of the role of student ethics in the learning development process in the Polimdo accounting department. 


\section{c. Responsible}

Responsibility towards oneself demands the awareness of each student to fulfill his obligations in developing his personality as an ethical human being. This responsibility is evidenced by the student's compliance with the rules applied in Polimdo, especially the accounting department. Responsibility is very important to be taught to students because with the responsibility of students, it is able to finish college on time so that parents feel proud of their children's success. Responsibilities as a student such as paying single tuition fees on time, and keeping campus assets / facilities clean, and functioning properly. Paying single tuition on time, of course, is very good for these students because they can attend courses regularly. Late tuition fees are very disturbing to lecture activities because students will be given leave sanctions. Therefore, students must be able to protect their parents' feelings. If the money sent for the single tuition fee is used properly, do not use the money for unnecessary things. Responsibilities as a student have a target to pass on time. Graduated on time, of course, it takes a struggle to have an attitude of never giving up. The assignments given by the lecturer are completed on time. Entering college is never late and actively asks if something material is deemed not understood. Attitudes in class and outside the classroom must be polite.

\section{d. Cooperation}

Cooperation is a form of social interaction, with an associative nature that occurs when groups of students who have the same views, to achieve common goals. As social creatures, of course students cannot rely on themselves to get maximum results. Collaboration will be able to provide many benefits, when a group assignment is given by the lecturer to do it together. Benefits of student cooperation when completing group work: a). Group assignments will be easier to complete. b). Group assignments can train each individual to issue opinions, suggestions, criticism and respect the opinions of others when sitting together completing group assignments. c). Group assignments will be easier to achieve the desired goals. d). Group assignments are able to foster a group learning spirit, and foster a sense of brotherhood. Collaboration can be a learning material for students while sitting in college. Building cooperation will be easier than working alone. Therefore, as a student, it is necessary to foster cooperation, so that group assignments or assignments that involve more than one student can be completed properly.

\section{e. Socialization}

Socialization is a learning process carried out by students to do, or behave based on standards that will be recognized by Polimdo, especially the accounting department. Student socialization to learn and adapt to values, norms, behavior, customs, and all other requirements needed to play a role and function in the lecture process. Socializing with friends, the socialization process is an active process, that is, a student belongs to a group. If students can adjust to the changes that occur in the social environment, these students will continue to grow and develop together with other students. Why do students need to socialize on campus because students are social creatures, and can live alone. When students can understand the differences in both characteristics, culture and customs, and are able to learn values, norms and roles, the student will live well, on campus or where the student lives. As it is known that the world of campus, not only teaches students in pursuing value targets, but also implies teaching students how to interact with friends on campus. Therefore, in campus life, the opportunities for students to develop their personal life are so great. Student life is a life full of struggles, away from parents and have to work, for the sake of a bright future. This hard student life is a lesson for the formation of human nature.

\section{f. Mutual respect}

Mutual Respect, multiculturalism opens space for students to respect each other's differences even though there are inconveniences. Tolerance on campus must be upheld because students are required to be respectful and respectful between groups, or between individuals, be it on campus, or in other environments. This is because each campus is followed by students from various regions who have different languages, cultures and religions. The formation of a student's character, seen from how students respect each other between fellow students at the same level as seniors and juniors, as well as lecturers and employees. Mutual respect is very visible when holding group discussions, or group assignments. How ethics of mutual respect will emerge among fellow students. When completing group assignments, the opinions of fellow friends must be respected even if they are not correct. Then, discussed patiently to find the correct answer solution. The main thing is that opinion must be accepted first, not rejected before discussion. Attitudes like this need to be exemplified, in order to create good ethics in terms of mutual respect for fellow friends at the Polimdo campus, especially in the accounting department.

\section{CONCLUSION}

Education at Polimdo, especially in the accounting department, aims to produce graduates with high ethical and moral standards. Various attempts were made to introduce ethical values to students, especially students majoring in accounting at Polimdo. In an effort to develop learning that is based on ethics, there is a need for feedback from the students themselves to improve good behavior. Therefore, ethics plays an important role in the development of learning in the Polimdo accounting department.

The research method used is descriptive qualitative method, which describes and describes the impact of the ethical role of students in the learning development process in the Polimdo accounting department. Data collection techniques, namely by direct observation, interviews using six informants, namely five students and one lecturer, and supported by literature study. 
The results of this study illustrate that the role of student ethics in the development and learning process in the Polimdo accounting department has been implemented properly, and is in accordance with what is taught by the lecturer. The ethics in the relationship between students and lecturers, namely;

1. Present on time, motivating students to live disciplined lives. Being present on time in every lecture, of course for students will have a good impact on these students, namely students can attend lectures from start to finish well, have satisfactory grades and can graduate on time. Graduating on time will certainly save costs, be able to reach goals faster, are proud of graduating with classmates, parents are very proud because their children graduate on time, they are not ashamed to be said that students are eternal and will be very appreciated, so that a personal trust arises as a student who discipline.

2. Polite manners are the rules of life that arise from the association of a group of students, namely: Obeying institutional regulations, respecting lecturers, respecting the lessons explained by the lecturers, not saying dirty words (harsh), not spitting and littering, not interrupting conversations, and dress manners. Students are educated people, whose daily behavior will be an example for their fellow students. Students have good behavior, without realizing their behavior has been assessed by the lecturer, and can have a positive influence on friends around them, or vice versa if students behave poorly then without realizing it, it has a negative influence on other students.

3. Responsibility demands awareness of every student, to fulfill his own obligations in developing his personality as an ethical student. This responsibility is evidenced by the student's compliance with the rules applied in Polimdo, especially the accounting department. It is very important to teach students responsibility because of the responsibility of these students, being able to finish college on time so that parents feel proud of their children's success.

4. Collaboration is a form of social interaction with an associative nature, which occurs when groups of students who have the same viewpoint achieve mutual benefits. Benefits of student cooperation when completing group work: a). Group assignments will be easier to complete. b). Group assignments can train each individual to issue opinions, suggestions, criticism and respect the opinions of others when sitting together completing group assignments. c). Group assignments will be easier to achieve the desired goals. d). Group assignments, able to foster a spirit of group learning, and foster a sense of brotherhood.

5. Socialization is a learning process, to learn and adapt to values, norms, behavior, customs, and all other requirements needed to play a role and function in the lecture process. Socializing with friends, the socialization process is an active process, that is, a student belongs to a group. If students can adjust to the changes that occur in the social environment, these students will continue to grow and develop together with other students. Therefore, in life on campus, the opportunities for students to develop their personal life are so great.

6. Mutual respect, multiculturalism opens space for students to respect each other's differences, even if there are inconveniences. Tolerance on campus must be upheld because students are required to respect each other between groups or between individuals, be it on campus or in other environments. This is because each campus is followed by students from various regions, who have differences in language, culture and religion.

\section{REFERENCES}

Abdullah Idi, Safarina, Educational Ethics, Jakarta: Rajawali Pers, 2015.

Chua, WF. 2007. "Radical Development in Accounting Thought". The Accounting

Kamayanti, dkk. 2012. PhilosophicalReconstruction of Accounting Education.World Journal of Social Sciences.(Vol. 2, No7, November 2012 Issue. Pp. 222-233).

Keraf, A. Sony. 1998. Business Ethics Demands and relevance. Yogyakarta: Kanisius

Ludigdo, Unti. 2010. Interpreting Indonesian Accountants' Professional Ethics with Pancasila. Inauguration speech for Professor of Ethics and Professionals at the Faculty of Economics and Business Universitas Brawijaya. Malang. 24 April 2010.

Mulawarman, Aji Dedi dan Unti Lundigdo. 2010. Metamorphosis of Accounting Students Holistic Ethical Awareness, Implementation of Learning Business Ethics, and IESQ-Based Professions.. Jurnal Akuntansi Multiparadigma (Vol. 1, Nomor 3, Desember 2010, 429-444).

Utami, Wiwik \& Indriawati, Fitri. 2005. Ethical Content in Financial Accounting Teaching and Its Impact on Students' Ethical Perceptions: Studi Eksperimen S http://akuntansi-management.blogspot.com/2011/08/perilaku-etika-dalam-profesiakuntansi.html 